\title{
Mild Dysplasia
}

National Cancer Institute

\section{Source}

National Cancer Institute. Mild Dysplasia. NCI Thesaurus. Code C8362.

A morphologic finding indicating the presence of mild cellular atypia associated with mild architectural changes in a tissue sample. 